\title{
Role Effectiveness Bhabinkamtibmas In Effort To Prevent And Eradicate Criminal Acts Of Domestic Violence
}

\author{
Teguh Wibowo*) and Siti Ummu Adillah**) \\ *) Universitas Islam Sultan Agung (UNISSULA) Semarang, E-mail: \\ firmw_mh36@std.unissula.ac.id \\ **) Faculty of Law, Universitas Islam Sultan Agung (UNISSULA) Semarang
}

\begin{abstract}
This writing aims to find out and analyze the effectiveness of role Bhabinkamtibmas in preventing cases of domestic violence in rural areas. The type of research used in this study is a type of legal research juridic-sociological. The approach uses sociological juridical. In principle, the duties of the police universally are to protect (protections), provide services to the community (services), enforce the law and maintain order (law enforcement and maintain law and order). Including roles of Bhabinkamtibmas in preventing and reducing the number of domestic violence in rural areas, the existence of various problems and weaknesses in the form of the lack of facilities and infrastructure as well as community culture make the role of Bhabinkamtibmas in preventing and reducing the number of domestic violence in rural areas has not been effective, one of which is shown in the Grobogan area, especially in the Keradenan area, where domestic violence is dominated by physical violence. So it is necessary to involve the community and increase information facilities and infrastructure through the use of digitalization related to the presence of Domestic Violence in rural areas. This can be seen in prevention of cases of Domestic Violence in rural areas in Grobogan is still quite high, this view is shown by the fact that there have been 20 cases of Domestic Violence in the Grobogan area, 11 cases occurred in Keradenan Village, Grobogan Regency where physical violence dominates.

Keywords: Bhabinkamtibmas; Effectiveness; Crime; Domestic Violence.
\end{abstract}

\section{Introduction}

The Unitary State of the Republic of Indonesia is a State based on law (rechtsstaat), not based on mere power (machtsstaat), this is confirmed in the General explanation of the 1945 Constitution of the Unitary State of the Republic of Indonesia. This shows that Indonesia is a State of Law. ${ }^{1}$ This has consequences for the Indonesian state which accepts law as an ideology in order to create security, justice, order, as well as provide welfare for all citizens of the unitary republic of Indonesia. Any changes to the law must be in accordance with the existing rules without exception. ${ }^{2}$ Law is the rule of the game for all human interactions in the

\footnotetext{
1Ibnu Suka, Gunarto, and Umar Ma'ruf, “Peran Dan Tanggung Jawab Polri Sebagai Penegak Hukum Dalam Melaksanaan Restorative Justice Untuk Keadilan Dan Kemanfaatan Masyarakat", Jurnal Hukum Khaira Ummah Vol. 13. No. 1 March 2018, p. 115-116.

2 Rully Trie Prasetyo, Umar Ma'ruf, dan Anis Mashdurohatun, "Tindak Pidana Korporasi Dalam Perspektif Kebijakan Formulasi Hukum Pidana”, Jurnal Hukum Khaira Ummah Vol. 12. No. 4 December, 2017, p. 729-730.
} 
life of the nation and state, so that people respect the law, then the law must be authoritative so that all legal subjects can obey. ${ }^{3}$

Indonesia enforces Criminal Law to ensure the implementation of legal protection to the public in general, where in practice Criminal Law refers to the Criminal Code (hereinafter referred to as the Criminal Code). The National Police is a tool for maintaining state security which has the task of maintaining security and public order, as well as enforcing the law, as well as providing shelter, service and protection to the community, enforcing the law, and providing protection, protection, and services to the community to maintain and maintain security and safety also the order of the Republic of Indonesia. The Indonesian National Police is the National Police of the Republic of Indonesia whose purpose is to create security and public order. ${ }^{4}$

According to Article 1 paragraph (1) of Act No. 23 of 2004 concerning the Elimination of Domestic Violence (UU PKDRT), is any act against a person, especially a woman, which results in physical, sexual, psychological misery or suffering, and/or neglect household including threats to commit acts, coercion, or deprivation of liberty unlawfully within the scope of the household. ${ }^{5}$

The crime of violence against women has received national and international attention. However, the number of violence against women shows an increasing trend from year to year. National Commission for Women noted that there were 77 cases of domestic violence in 2020.6This is not due to the ability of legal regulations that cannot reach cases of domestic violence in rural areas, but the various problems that exist in the village in the form of the absence of intervention and awareness from various parties, both parties who commit domestic violence, victims, and parents. The existence of community leaders in solving domestic violence problems is also considered important, because community leaders have a big role to help the community in solving various problems, including cases of domestic violence. ${ }^{7}$ Community leaders in overcoming this are the Head of RT/RW, Village Head, and Ulama (Religious Leaders). Intervention from these parties is very much needed to reduce the occurrence of increasing cases of domestic violence. ${ }^{8}$

Bhabinkamtibmas is a National Police officer on duty at the village to subdistrict level who is tasked with carrying out pre-emptive functions by partnering

\footnotetext{
${ }^{3}$ Abdul Wahid and Muhammad Irfan, Perlindungan Terhadap Korban Kekerasan Seksual, Refika Aditama, Bandung, 2001, p. 30.

4 Warsito Hadi Utomo, 2005, Hukum Kepolisian di Indonesia, Jakarta: Prestasi Pustaka, p. 536.

${ }^{5}$ Arif Septria Hendra Saputra, Gunarto, and Lathifah Hanim, Penerapan Restoratife Justice Sebagai Alternatif Penyelesaian Tindak Pidana Penganiayaan Di Satreskrim Polsek Lasem, Jurnal Daulat Hukum Vol. 1. No. 1 March 2018, p. 159.

6https://komnasperempuan.go.id/siaran-pers-detail/catahu-2020-komnas-perempuan-lembarfact-dan-poin-key-5-maret-2021, accessed on March 13, 2021.

${ }^{7}$ Angga Aula Budhy Pradewa and Jawade Hafidz, Akibat Hukum Kekerasan Dalam Rumah Tangga Yang Dilakukan Suami Terhadap Istri Ditinjau Dari Uu No 23 Tahun 2004 Dan Hukum Islam, Prosiding KONFERENSI ILMIAH MAHASISWA UNISSULA (KIMU) 2, Universitas Islam Sultan Agung Semarang, 18 October 2019, p. 743-744.

8 Op, cit, Abdul Wahid and Muhammad Irfan.
} 
with the community. Bhabinkamtibmas is an abbreviation of "Bhayangkara is Leader of Public Security and Order".

Based on the Decree of the Head of the National Police of the Republic of Indonesia No.Pol.KEP/8/II/2009 regarding the change of the National Police Chief Field Manual No.Pol::BUJUKLAP/17/VII/1997 concerning the designation of Bhabinkamtibmas (Bintara is leader Kamtibmas) to Bhabinkamtibmas (Bhayangkara is leader Kamtibmas) from the rank of Brigadier to Inspector. As a member of Bhabinkamtibmas who is in the midst of society, he must be able to be a role model and protector of the community at the smallest community level, namely the village, able to hear more clearly about what people complain about. Bhabinkamtibmas does not have to be able to solve all problems at the village level, but Bhabinkamtibmas must be able to facilitate these problems to be resolved through a more appropriate forum, both through FKPM and partnership forums with government agencies at the village level and stakeholders in the community. The daily activities that must be carried out by Bhabinkamtibmas are visiting people's homes. ${ }^{9}$ In principle, Bhabinkamtibmas activities only need 4 D (Come-SitListen-Dialogue) and $1 \mathrm{C}$ (Note). ${ }^{10}$

The implementation of Bhabinkamtibmas' role in reducing the number of domestic violence in rural areas is not easy, the uncooperative attitude of the villagers, the existence of a culture of domestic violence as a disgrace that must be covered up and the culture that other people are not good at interfering in the resolution of domestic violence have made Bhabinkamtibmas. The Purwodadi area is no exception. According to Citra Ayu as the Director of LRC KJHAM that in 2020 there have been 83 cases of domestic violence in the Grobogan area. ${ }^{11}$ Kedungrejo Village is the village with the highest level of domestic violence, which is 53 cases, and in Keradenan Village it is 30 cases. ${ }^{12}$ In addition, the existence of economic problems and the level of education have also contributed to the occurrence of domestic violence in rural areas. This writing aims to find out and analyze the effectiveness of role Bhabinkamtibmas (Bhayangkara is leader Kamtibmas) in preventing cases of domestic violence in rural areas.

\section{Research Methods}

The type of research used in this study is a type of legal research juridical sociological. The approach uses sociological juridical, the specification in this writing is analytical descriptive. Methods of collecting data by means of field studies and literature studies. Methods of data analysis using qualitative methods.

\footnotetext{
${ }^{9}$ Siti Ummu Adillah Dan Sri Anik, Kebijakan Jaminan Sosial Tenaga Kerja Sektor Informal Berbasis Keadilan Sosial Untuk Meningkatkan Kesejahteraan, Jurnal Yustisia, Vol. 4 No. 3 September December 2015, p. 559-560.

10 http://tribratanews.demak.jateng.polri.go.id/function-dan-peran-bhabinkamtibmas/, accessed on March 12, 2021.

11https://kbr.id/nasional/11-

020/sepanjang_2020_83_case_violence_to_perempuan_terjadi_di_jateng/104132.html, Retrieved 20 March 2021.

${ }^{12}$ AKP Eko Bambang Nurtjahyo, Personal Interview with Head of Criminal Investigation Unit of Grobogan Police, Interview conducted on 12 June 2021
} 


\section{Result and Discussion}

\subsection{Role Execution Bhabinkamtibmas (Bhayangkara is leader Kamtibmas) In Preventing Current Cases of Domestic Violence}

In principle, the duties of the police universally are to protect (protection), provide services to the community (services), enforce the law and maintain order (law enforcement and maintain law and order). The functions and roles and duties of the police are clearly inseparable from the existing laws and regulations, especially Act No. 2 of 2002 concerning the Indonesian National Police, because the tasks carried out by the police, especially in the field of law enforcement (repressive) always intersect with the rights of the police. Human Rights, even from several elements of law enforcement related to the integrated criminal justice system, the police are always the first and foremost in contact with human rights. ${ }^{13}$ In addition, there are quite a lot of powers given to the police by the state. In line with the breadth of authority given by the state to the police institution, the police's duties are always vulnerable to deviations from duties that result in violations of human rights. ${ }^{14}$ In subsequent developments there are laws and regulations that are scattered and specific, for example Government Regulation Number 2 of 2002 concerning Procedures for the Protection of Victims and Witnesses in Serious Human Rights Violations. The forms of providing this protection are: (a) for personal security of victims or witnesses from physical threats, (b) confidentiality of the identities of victims or witnesses, (c) giving information during examinations in court without meeting the suspect face to face. In Act No. 23 of 2004 concerning the Elimination of Domestic Violence, it is expressly regulated for the protection of victims as stipulated in Articles 16 to 38 .

So that almost half of the substance of this Law actually regulates the protection of victims. The protection referred to here is the protection as stipulated in Article 1 point 4 of Act No. 23 of 2004, namely: "All efforts aimed at providing a sense of security to victims are carried out by families, advocates, social institutions, police, prosecutors, courts , or other parties either temporarily or based on a court order". In providing protection to victims of domestic violence, the National Police plays a very important role, especially in providing temporary protection,

Repressive actions in the form of investigations and investigations are to enforce the law in relation to the politics of criminalization that has been stipulated in the formulation of criminal sanctions against violators who are suspected of having committed criminal acts. Prioritizing the function of the police in providing protection to victims of domestic violence is a reflection of the strategy that has been launched by the UN General Assembly on the Model Strategy and Practical Steps for the Elimination of Violence Against Women in Crime and

\footnotetext{
${ }^{13}$ Sarwadi dan Bambang Tri Bawono, Restorative Justice Approach in Diversion System for Settlement of Criminal Cases for Children in Indonesia, Jurnal Daulat Hukum Volume 3 Issue 4, December 2020, p. 377-400.

${ }^{14}$ Dwi Kurniawan, Implementation Of Legal Protection Of Children As Victims Of Domestic Psychic Violence, Jurnal Daulat Hukum, Volume 1. No. 2 June 2018, p. 398-399.
} 
Criminal Justice in Part III concerning the Police by stating the provisions as follows:

- to ensure that the prevailing laws, regulations and procedures relating to violence against women are always enforced consistently and in such a way that all criminal acts of violence against women can be immediately identified and acted upon as necessary by the criminal justice system;

- to develop investigative techniques that do not demean women victims of violence, and minimize harassment, while maintaining the best possible standards for gathering evidence;

- to ensure that police procedures including decisions on detention, imprisonment, and conditions for the release of perpetrators must take into account the safety of victims and other persons involved through family, community or other relationships, and must ensure that these procedures prevent further acts of violence;

- to empower the police to act immediately in cases of violence against women;

- to ensure that the exercise of police powers is carried out in accordance with statutory rules and regulations of conduct, and that the police can be held accountable if there are violations of these matters;

- to encourage women to join the police force, including the operational ranks.

With regard to the provision of protection by the police to victims of domestic violence, absolutely strong support from the government and regional governments to prepare facilities and infrastructure as stipulated in Article 13 letter a which stipulates: "For the provision of services to victims, the government, and the government regions in accordance with their respective functions and duties can provide special service rooms at the police office". Of course the provision of this facility depends on the state's financial condition for its provision. The main function of the police is to enforce the law and serve the interests of the general public, therefore it can be said that the task of the police is to prevent crime and provide protection to the public.

\subsection{Effectiveness Role Bhabinkamtibmas (Bhayangkara is leader Kamtibmas) In Preventing Cases of Domestic Violence in Rural Areas}

The United Nations Declaration on the Elimination of Violence Against Women (1993) defines violence against women as "all forms of violent behavior experienced by women, both in the surrounding community and in personal life, physically, mentally, or in terms of neglect of women itself (coercion, arbitrary deprivation) both in the surrounding community and in personal matters".

While the Law of the Republic of Indonesia No. 23 of 2004 concerning the Elimination of Domestic Violence Article 1 defines domestic violence (KDRT) as:

Any action directed at women who in this case are victims, which will have an impact on physical, sexual or psychological misery or suffering. Actions that are very detrimental to women in this case are in the form of confiscation, coercion, threats to commit acts that occur within the scope of the household.

In its development, the implementation of preventing cases of Domestic Violence in rural areas in Grobogan is still quite high, according to AKP Eko 
Bambang Nurtjahyo as Head of Criminal Investigation Unit of the Grobogan Police, there have been 20 cases of Domestic Violence in the Grobogan area, 11 cases occurred in Keradenan Village, Grobogan Regency where physical violence predominates. ${ }^{15}$ This shows that the role Bhabinkamtibmas is still not effective. This is because information facilities and infrastructure are still limited, namely the lack of community, victim and victim families who are informative about the existence of domestic violence, the culture of the community who feels that domestic violence is a family problem that is considered disgraceful so it is unethical to report it to Bhabinkamtibmas ${ }^{16}$

\section{Closing}

In principle, the duties of the police universally are to protect (protections), provide services to the community (services), enforce the law and maintain order (law enforcement and maintain law and order). Including roles of Bhabinkamtibmas in preventing and reducing the number of domestic violence in rural areas, the existence of various problems and weaknesses in the form of the lack of facilities and infrastructure as well as community culture have made the role of Bhabinkamtibmas in preventing and reducing the number of domestic violence in rural areas not yet effective, one of which is shown in the Grobogan area, especially in the Keradenan area, where domestic violence is dominated by physical violence. So it is necessary to involve the community and increase information facilities and infrastructure through the use of digitalization related to the presence of Domestic Violence in rural areas.

\section{References}

\section{Journal}

[1] Angga Aula Budhy Pradewa and Jawade Hafidz, "Akibat Hukum Kekerasan Dalam Rumah Tangga Yang Dilakukan Suami Terhadap Istri Ditinjau Dari Uu No 23 Tahun 2004 Dan Hukum Islam", Prosiding KONFERENSI ILMIAH MAHASISWA UNISSULA (KIMU) 2, Universitas Islam Sultan Agung Semarang, 18 October 2019

[2] Arif Septria Hendra Saputra, Gunarto, and Lathifah Hanim, "Penerapan Restoratife Justice Sebagai Alternatif Penyelesaian Tindak Pidana Penganiayaan Di Satreskrim Polsek Lasem", Jurnal Daulat Hukum Vol. 1. No. 1 March 2018

[3] Dwi Kurniawan, "Implementation Of Legal Protection Of Children As Victims Of Domestic Psychic Violence", Jurnal Daulat Hukum, Volume 1. No. 2 June 2018

[4] Ibnu Suka, Gunarto, and Umar Ma'ruf, "Peran Dan Tanggung Jawab Polri Sebagai Penegak Hukum Dalam Melaksanaan Restorative Justice Untuk

\footnotetext{
15 AKP Eko Bambang Nurtjahyo, Personal Interview with Head of Criminal Investigation Unit of Grobogan Police, Interview conducted on 12 June 2021.

16 Loc, cit.
} 
Keadilan Dan Kemanfaatan Masyarakat", Jurnal Hukum Khaira Ummah Vol. 13. No. 1 March 2018

[5] Rully Trie Prasetyo, Umar Ma'ruf, and Anis Mashdurohatun, "Tindak Pidana Korporasi Dalam Perspektif Kebijakan Formulasi Hukum Pidana”, Jurnal Hukum Khaira Ummah Vol. 12. No. 4 December 2017

[6] Sarwadi and Bambang Tri Bawono, "Restorative Justice Approach in Diversion System for Settlement of Criminal Cases for Children in Indonesia", Jurnal Daulat Hukum Volume 3 Issue 4, December 2020

[7] Siti Ummu Adillah and Sri Anik, "Kebijakan Jaminan Sosial Tenaga Kerja Sektor Informal Berbasis Keadilan Sosial Untuk Meningkatkan Kesejahteraan", Jurnal Yustisia, Vol. 4 No. 3 September - December 2015

\section{Book}

[1] Abdul Wahid dan Muhammad Irfan, 2001, Perlindungan Terhadap Korban Kekerasan Seksual, Refika Aditama, Bandung,

[2] Warsito Hadi Utomo, 2005, Hukum Kepolisian di Indonesia, Prestasi Pustaka, Jakarta

\section{Interview}

[1] AKP Eko Bambang Nurtjahyo, Personal Interview with Head of Criminal Investigation Unit of Grobogan Police, Interview conducted on 12 June 2021

\section{Internet}

[1] http://tribratanews.demak.jateng.polri.go.id/function-dan-peranBhabinkamtibmas/, Accessed on March 12, 2021

[2] https://komnasperempuan.go.id/siaran-pers-detail/catahu-2020-komnasperempuan-lembar-fact-dan-poin-key-5-maret-2021, Accessed on March 13, 2021

[3] https://kbr.id/nasional/11020/sepanjang_2020__83_case_violence_to_pere mpuan_terjadi_di_jateng/104132.html, Accessed on March 20, 2021 